\title{
Status gizi dan perkembangan anak usia 3-5 tahun di Kabupaten Bogor
}

\author{
Sarah Melati Davidson ${ }^{*}$, Ali Khomsan ${ }^{2}$, Hadi Riyadi²
}

\section{ABSTRACT}

Background: Malnutrition in children under five causes a variety of developmental disorders. The nutritional need for children aged 3-5 age is very critical to reach optimum growth and development.

Objectives: The purpose of this study is to analyse the association between nutritional status using WAZ, HAZ, WHZ index with gross motor, fine motor, passive communication, active communication, cognitive, self-help ability and social behavior development childred aged 3-5 years old.

Methods: Data was obtained from a study entitled Improving Child Growth and Development through Nutrition and Psychosocial Intervention in Early Childhood Education (PAUD) Setting in Rural Areas and was fully funded by the Nestle Foundation (NF), Switzerland. The study design was cross-sectional, with 120 children aged 3-5 years old as subjects. Locations and subjects were selected purposively in Bogor District. Nutritional status was assesed by WAZ, HAZ, and WHZ index. Child development was assessed by using Bina Keluarga Balita questionnaire.

Results: Most of the subjects had good nutritional status dan development level. WAZ indicator significantly associated with gross motor dan cognitive development $(p<0.05)$. HAZ indicator significantly associated with gross motor, active communication skills and cognitive development $(p<0.05)$. WHZ indicator significantly associated with fine motor and cognitive children ( $p<0.05)$.

Conclusion: Nutritional status is associated with child development.

Keywords: child development; child growth; nutritional status

\section{ABSTRAK}

Latar Belakang: Masalah gizi pada anak bawah 5 tahun menyebabkan gangguan perkembangan. Pemenuhan kebutuhan gizi anak usia 3-5 tahun sangat penting untuk mendukung pertumbuhan dan perkembangan.

Tujuan: Untuk mengetahui hubungan status gizi $B B / U, T B / U$, dan BB/TB dengan perkembangan motorik kasar, motorik halus, komunikasi pasif, komunikasi aktif, kognitif, kemampuan menolong diri sendiri, dan tingkah laku sosial anak usia 3-5 tahun.

Metode: Data diperoleh dari penelitian Improving Child Growth and Development through Nutrition and Psychosocial Intervention in Early Childhood Education (PAUD) Setting in Rural Areas yang didanai penuh oleh Nestle Foundation (NF) Switzerland. Desain penelitian ini adalah cross-sectional study dengan melibatkan 120 anak usia 3-5 tahun. Lokasi dan subjek dipilih secara purposive di Kabupaten Bogor. Status gizi anak dinilai berdasarkan indeks BB/U, TB/U dan BB/TB. Perkembangan anak dinilai dengan menggunakan kuesioner Bina Keluarga Balita (BKB).

Hasil: Sebagian besar subjek memiliki status gizi yang baik dan tingkat perkembangan yang baik. Status gizi BB/U signifikan berhubungan dengan perkembangan motorik kasar dan kognitif anak ( $p<0,05)$. Status gizi $T B / U$ signifikan berhubungan dengan perkembangan motorik kasar, komunikasi aktif, dan kognitif anak ( $p<0,05)$. Status gizi BB/TB signifikan berhubungan dengan perkembangan motorik halus dan kognitif anak $(p<0,05)$.

Simpulan: Terdapat hubungan status gizi dengan perkembangan anak

Kata kunci: perkembangan anak; pertumbuhan anak; status gizi

\section{PENDAHULUAN}

Kebutuhan gizi anak usia balita (bawah lima tahun) sangat penting, karena pertumbuhan dan perkembangan secara pesat terjadi pada kelompok usia ini. ${ }^{1}$ Pemberian gizi seimbang pada periode ini dilakukan untuk mendukung perkembangannya secara optimal. Periode ini bersifat irreversible, yang berarti tidak dapat diperbaiki di fase kehidupan berikutnya dan akan memengaruhi outcome pada masa anak-anak dan dewasa. ${ }^{2}$ Idealnya perkembangan anak sejalan dengan pertumbuhan. Kompleksitas sistem jaringan otot, sistem syaraf serta sistem fungsi organ tubuh sejalan dengan proses pematangan fisik atau pertumbuhan. Kekurangan gizi pada anak balita berdampak pada gangguan pertumbuhan yang mengakibatkan gangguan terhadap perkembangan anak. ${ }^{3}$ Dengan demikian status gizi sangat menentukan perkembangan di kemudian hari.

Secara global masalah gizi anak balita berdasarkan data berat badan menurut usia $(\mathrm{BB} / \mathrm{U})$, tinggi badan menurut usia $(\mathrm{TB} / \mathrm{U})$, dan berat badan menurut tinggi badan (BB/TB) masih sangat tinggi dan menjadi

\footnotetext{
${ }^{1}$ Program Studi Gizi, Fakultas Kedokteran dan Ilmu Kesehatan, Universitas Kristen Satya Wacana. J1. Kartini No.11 A, Salatiga, Jawa Tengah 50711, Indonesia ${ }^{2}$ Departemen Gizi Masyarakat, Fakultas Ekologi Manusia, Institut Pertanian Bogor. Jl. Lingkar Kampus, Kampus IPB Dramaga, Bogor, Jawa Barat 16680, Indonesia

"Korespondensi : E-mail: smd.sarahmelati@gmail.com
} 
tantangan kesehatan terutama bagi negara berkembang. ${ }^{4}$ Hasil Riset Kesehatan Dasar (Riskesdas) 2018 menunjukkan prevalensi nasional anak balita yang mengalami masalah gizi underweight berdasarkan indeks $\mathrm{BB} / \mathrm{U}$ sebanyak $17,7 \%$, stunting berdasarkan indeks $\mathrm{TB} / \mathrm{U}$ sebanyak $30,8 \%$ dan wasting berdasarkan indeks $\mathrm{BB} / \mathrm{TB}$ sebanyak $10,2 \%$ wasting. ${ }^{5}$ Jawa Barat diketahui memiliki prevalensi underweight, stunting dan wasting sebesar 14,6\%, 31,1\%, dan 8,5\%. Dinas Kesehatan Kabupaten Bogor mencatat sebanyak 24.592 anak gizi kurang dan 4.264 anak gizi buruk. ${ }^{6}$ Masalah kekurangan gizi akan berdampak pada gangguan pertumbuhan, rentan terhadap infeksi, dan dapat menghambat perkembangan anak. Beberapa penelitian menemukan hasil bahwa stunting dan underweight berhubungan dengan perkembangan anak terutama pada perkembangan motorik, kognitif, dan bahasa anak. ${ }^{7,8,9}$

Penting untuk memastikan bahwa anak-anak berkembang secara optimal. Banyak anak yang mengalami keterlambatan perkembangan karena keterbatasan ekonomi, status gizi, kondisi kesehatan serta pengasuhan yang kurang tepat. ${ }^{10,11}$ Lebih dari 200 juta anak balita ditemukan tidak berkembang sesuai umur. Kebanyakan ditemukan di daerah Asia dan Afrika bagian sahara yang salah satunya disebabkan karena asupan gizi yang tidak adekuat. ${ }^{12}$ Riskesdas 2018 mencatat indeks perkembangan anak usia 3-5 tahun yang telah sesuai dengan usia (on track) adalah sebesar 88,3\%. Perkembangan anak usia 3-5 tahun di daerah perdesaan masih dibawah angka nasional yaitu sebesar $86,7 \%$ dan lebih rendah dibandingkan dengan perkembangan indeks perkembangan anak di daerah perkotaan. ${ }^{5}$ Penelitian ini dilakukan untuk melengkapi hasil penelitian-penelitian sebelumnya yang kebanyakan peneliti hanya yang menampilkan hubungan status gizi dengan beberapa aspek perkembangan anak. Tujuan penelitian ini untuk mengetahui hubungan antara tiga indeks status gizi yaitu berdasarkan indeks berat badan menurut usia $(\mathrm{BB} / \mathrm{U})$, tinggi badan menurut usia $(\mathrm{TB} / \mathrm{U})$, dan berat badan menurut tinggi badan $(\mathrm{BB} / \mathrm{TB})$ dengan tujuh aspek spesifik perkembangan anak meliputi perkembangan motorik kasar, motorik halus, komunikasi pasif, komunikasi aktif, kognitif, kemampuan menolong diri sendiri, dan tingkah laku sosial pada anak usia 3-5 tahun di daerah perdesaan.

\section{BAHAN DAN METODE}

Penelitian ini menggunakan data dari riset kerjasama Institut Pertanian Bogor (IPB) dengan Nestle Foundation (NF) Switzerland yang berjudul Improving Child Growth and Development through Nutrition and Psychosocial Intervention in Early Childhood Education (PAUD) Setting in Rural Areas. Desain penelitian yang digunakan adalah cross-sectional study. Lokasi penelitian bertempat di Kecamatan Tamansari dan
Kecamatan Dramaga, Kabupaten Bogor, Jawa Barat pada Desember 2017 - Maret 2018. Subjek penelitian berjumlah 120 orang dipilih secara purposive berdasarkan kriteria inklusi, yaitu: 1) berusia 3-5 tahun sesuai dengan indikator bina keluarga balita (37-59 bulan); 2) mempunyai orang tua lengkap dan bersedia berpartisipasi dalam penelitian; 3) tidak mempunyai cacat atau kelainan bawaan. Penelitian ini telah mendapat persetujuan etik dari Komisi Etik Penelitian Kesehatan Fakultas Kesehatan Masyarakat Universitas Diponegoro No.83/EC/FKM/2017.

Data yang dikumpulkan meliputi data karakteristik subjek, antropometri, perkembangan, serta pengetahuan, sikap, dan praktik gizi ibu. Berat badan anak diukur langsung menggunakan timbangan injak yang telah dikalibrasi dengan ketelitian $0,1 \mathrm{~kg}$. Sedangkan pengukuran tinggi badan anak menggunakan diukur menggunakan microtoise dengan ketelitian $0,1 \mathrm{~cm}$. Status gizi anak dinilai berdasarkan indeks BB/U, TB/U, dan $\mathrm{BB} / \mathrm{TB}$ dengan menggunakan $z$-score menurut nilai simpangan baku pertumbuhan World Health Organization (WHO). Data status gizi anak berdasarkan indeks $\mathrm{BB} / \mathrm{U}$ dikategorikan kedalam gizi kurang (underweight), gizi baik, dan gizi lebih. Berdasarkan indeks TB/U status gizi anak dikategorikan menjadi sangat pendek, pendek, dan normal. Status gizi indeks $\mathrm{BB} / \mathrm{TB}$ dikategorikan menjadi sangat kurus, kurus, normal, dan gemuk. Perkembangan anak dinilai dengan menggunakan instrumen kuesioner Bina Keluarga Balita (BKB) yang dikembangkan oleh Badan Kependudukan dan Keluarga Berencana Nasional (BKKBN). Instrumen ini terdiri atas tujuh aspek perkembangan yang biasa dipantau dalam pemantauan perkembangan yaitu motorik kasar, motorik halus, komunikasi pasif, komunikasi aktif, kognitif, kemampuan menolong diri sendiri (self-help), dan tingkah laku sosial yang penilaiannya dikelompokkan berdasarkan usia 3-4 tahun dan 4-5 tahun. Total skor penilaian perkembangan dikategorikan baik bila nilai yang diperoleh lebih besar dari nilai mean keseluruhan subjek. Data pengetahuan, sikap, dan praktik ibu dalam pemenuhan gizi dinilai dengan menggunakan kuesioner dengan ketentuan nilai 0 bila ibu menjawab salah dan nilai 1 bila ibu menjawab dengan benar. Total skor tersebut selanjutnya dikategorikan menjadi kurang bila jawaban benar $<60 \%$, cukup bila jawaban benar $60-80 \%$, dan baik bila jawaban benar $>80 \%$ dari total skor. ${ }^{13}$

Data yang diperoleh kemudian dilakukan proses editing, coding, processing, dan cleaning. Selanjutnya analisis univariat dilakukan untuk menggambarkan sebaran variabel berdasarkan persen dan rataan. Sebelum dilakukan analisis bivariat, data akan diuji normalitasnya menggunakan Kolmogorov-Smirnov. Analisis bivariat dengan uji korelasi spearman digunakan untuk mengetahui korelasi status gizi TB/U dengan tujuh aspek perkembangan anak dan uji korelasi pearson untuk 
mengetahui korelasi status gizi $\mathrm{BB} / \mathrm{U}$ dan $\mathrm{BB} / \mathrm{TB}$ dengan tujuh aspek perkembangan yang diteliti.

\section{HASIL}

\section{Karakteristik Subjek}

Jumlah subjek laki-laki dan perempuan dalam penelitian ini relatif seimbang yaitu $46,7 \%$ dan $53,3 \%$. Pengetahuan gizi ibu sebanyak 50\% sudah berada dalam kategori baik. Pengetahuan ibu merupakan tingkat pemahaman ibu mengenai prinsip pemberian makan kepada anak. Sikap gizi ibu terhadap sebanyak 49,2\% berada dalam kategori baik. Sikap ibu tersebut merupakan cerminan kesiapan atau kesediaan ibu untuk merespon segala sesuatu yang berkaitan dengan pemberian makan pada anak. Praktik gizi ibu merupakan kemampuan ibu didalam memberikan makan untuk memenuhi gizi anak dan penelitian ini menunjukkan sebanyak $66,7 \%$ sudah menerapkan praktik gizi yang baik. Pengetahuan, sikap, dan praktik gizi dalam pemberian makan anak akan mendukung anak memiliki kualitas konsumsi yang baik dan menjadi faktor utama dalam menurunkan penyakit infeksi dan meningkatkan status gizi. Hal ini mendukung perkembangan anak untuk lebih optimal. Selain itu, anak dengan masalah tumbuh kembang ditemukan lebih banyak didaerah dengan status ekonomi menengah kebawah. ${ }^{14}$

Tabel 1. Karakteristik Jenis Kelamin, Pengetahuan, Sikap, Serta Praktik Gizi Ibu

\begin{tabular}{lll}
\hline Variabel & n=120 & \% \\
\hline Jenis Kelamin & & \\
$\quad$ Laki-laki & 56 & 46,7 \\
$\quad$ Perempuan & 64 & 53,3 \\
Pengetahuan gizi Ibu & & \\
$\quad$ Kurang & 6 & 5 \\
$\quad$ Sedang & 54 & 45 \\
$\quad$ Baik & 60 & 50 \\
Sikap gizi Ibu & & \\
$\quad$ Kurang & 10 & 8,3 \\
$\quad$ Sedang & 51 & 42,5 \\
$\quad$ Baik & 59 & 49,2 \\
Praktik Gizi Ibu & & \\
$\quad$ Kurang & 11 & 9,2 \\
$\quad$ Sedang & 29 & 24,2 \\
Baik & 80 & 66,7 \\
\hline
\end{tabular}

\section{Status Gizi Anak}

Berdasarkan hasil penelitian ini sebagian besar subjek memiliki status gizi yang baik. Tabel 2 menunjukkan bahwa berdasarkan indeks BB/U sebanyak 19,2\% subjek mengalami gizi kurang (underweight). Sedangkan berdasarkan indeks TB/U 4,2\% subjek sangat pendek dan $20 \%$ pendek. Menurut indeks BB/TB diketahui sebanyak 1,7\% subjek sangat kurus dan $4,2 \%$ kurus. (Tabel 2).
Tabel 2. Status Gizi BB/U, TB/U, Dan BB/TB Subjek

\begin{tabular}{cll}
\hline Status Gizi Anak & $\mathbf{n = 1 2 0}$ & \% \\
\hline Status Gizi BB/U & & \\
Gizi Kurang & 23 & 19,2 \\
Gizi Baik & 94 & 78,3 \\
Gizi Lebih & 3 & 2,5 \\
Status Gizi TB/U & & \\
Sangat Pendek & 5 & 4,2 \\
Pendek & 24 & 20 \\
Normal & 91 & 75,8 \\
Status Gizi BB/TB & & \\
Sangat Kurus & 2 & 1,7 \\
Kurus & 5 & 4,2 \\
Normal & 109 & 90,8 \\
Gemuk & 4 & 3,3 \\
\end{tabular}

Tabel 3. Karakteristik Subjek Berdasarkan Pencapaian Aspek Perkembangan

\begin{tabular}{lll}
\hline Aspek Perkembangan & n=120 & \% \\
\hline Motorik Kasar & & \\
$\quad$ Kurang & 26 & 21,7 \\
$\quad$ Baik & 94 & 78,3 \\
Motorik Halus & & \\
$\quad$ Kurang & 39 & 32,5 \\
$\quad$ Baik & 81 & 67,5 \\
Komunikasi Pasif & & \\
$\quad$ Kurang & 43 & 35,8 \\
$\quad$ Baik & 77 & 64,2 \\
Komunikasi Aktif & & \\
$\quad$ Kurang & 51 & 42,5 \\
$\quad$ Baik & 69 & 57,5 \\
Kognitif & & \\
$\quad$ Kurang & 41 & 34,2 \\
$\quad$ Baik & 79 & 65,8 \\
Kemampuan menolong diri sendiri & & \\
$\quad$ Kurang & 45 & 37,5 \\
$\quad$ Baik & 75 & 62,5 \\
Tingkah laku sosial & & \\
$\quad$ Kurang & 38 & 31,7 \\
$\quad$ Baik & 82 & 68,3 \\
\hline
\end{tabular}

\section{Kategori Perkembangan Anak}

Penelitian ini menunjukkan bahwa motorik kasar pada sebagian besar subjek $(78,3 \%)$ sudah berkembang baik sesuai dengan usia. Perkembangan motorik halus anak sebagian besar $(67,5 \%)$ telah berkembang dengan baik. Sebanyak $64,2 \%$ anak juga telah memiliki perkembangan komunikasi pasif yang baik. Sebanyak $57,5 \%$ anak sudah memiliki perkembangan kemampuan komunikasi aktif yang sesuai dengan usia. Perkembangan kognitif anak yang sudah optimal sesuai dengan usianya sebanyak $65,8 \%$. Selain itu kemampuan anak dalam menolong diri sendiri (self-help) sebagian besar $(62,2 \%)$ sudah berkembang dengan baik dan sebanyak $68,3 \%$ anak yang memiliki perkembangan tingkah laku sosial yang baik. (Tabel 3). Perkembangan anak memiliki tahapannya sendiri sesuai dengan usia anak seiring dengan pertumbuhan sehingga idealnya 
setiap anak dapat mencapai tahapan perkembangan yang sesuai dengan usianya.

\section{Hubungan Status Gizi dengan Perkembangan Anak}

Berdasarkan hasil uji korelasi pearson diketahui status gizi indeks $\mathrm{BB} / \mathrm{U}$ berhubungan dengan perkembangan motorik kasar $(\mathrm{p}=0,002 ; \mathrm{r}=0,284)$ dan perkembangan kognitif anak $(\mathrm{p}=0,000 ; \mathrm{r}=0,314)$. Hasil penelitian ini juga menunjukkan bahwa semakin baik indeks $\mathrm{BB} / \mathrm{U}$ maka perkembangan motorik kasar dan kognitif anak akan semakin baik. Sedangkan perkembangan motorik halus, komunikasi pasif, komunikasi aktif, kemampuan menolong diri sendiri, dan tingkah laku sosial tidak berhubungan dengan status gizi $\mathrm{BB} / \mathrm{U}(\mathrm{p}>0,05)$. Berdasarkan uji korelasi spearman diketahui bahwa perkembangan motorik kasar $(\mathrm{p}=0,000$; $\mathrm{r}=0,353$ ), komunikasi aktif ( $\mathrm{p}=0,012 ; \mathrm{r}=0,228)$, dan kognitif $(\mathrm{p}=0,002 ; \mathrm{r}=0,285)$ berhubungan dengan status gizi indeks TB/U. Hal tersebut juga menunjukkan bahwa semakin baik indeks TB/U maka perkembangan motorik kasar, komunikasi aktif dan kognitif anak akan semakin baik. Namun, perkembangan motorik halus, komunikasi pasif, kemampuan menolong diri sendiri, dan tingkah laku sosial tidak berhubungan dengan status gizi TB/U ( $>0,05)$. Selanjutnya berdasarkan uji korelasi pearson diketahui bahwa status gizi $\mathrm{BB} / \mathrm{TB}$ berhubungan dengan perkembangan motorik halus $(\mathrm{p}=0,002 ; \mathrm{r}=0.276)$ dan perkembangan kognitif ( $\mathrm{p}=0,019 ; \mathrm{r}=0,214)$. Berdasarkan uji statistik tersebut juga diperoleh bahwa semakin baik indeks BB/TB maka perkembangan motorik halus dan kognitif anak akan semakin baik. Tabel 4 menunjukkan bahwa status gizi $\mathrm{BB} / \mathrm{TB}$ tidak berhubungan dengan perkembangan motorik kasar, komunikasi pasif, komunikasi aktif, kemampuan menolong diri sendiri, dan tingkah laku sosial $(p>0,05)$.

Tabel 4. Hubungan Status Gizi BB/U, TB/U, dan BB/TB dengan Perkembangan

\begin{tabular}{lcccccc}
\hline \multirow{2}{*}{ Variabel } & \multicolumn{2}{c}{$\mathbf{B B} / \mathbf{U}^{\mathbf{a}}$} & \multicolumn{2}{c}{$\mathbf{T B}^{\mathbf{b}} \mathbf{U}^{\mathbf{b}}$} & \multicolumn{2}{c}{$\mathbf{B B} / \mathbf{T B}$} \\
\cline { 2 - 7 } & $\mathbf{r}$ & $\mathbf{p}$ & $\mathbf{r}$ & $\mathbf{p}$ & $\mathbf{p}$ & 0,602 \\
Motorik kasar & 0,284 & $0,002^{*}$ & 0,353 & $0,000^{*}$ & 0,048 & $0,002^{*}$ \\
Motorik halus & 0,174 & 0,058 & 0,013 & 0,888 & 0,276 & 0,799 \\
Komunikasi pasif & 0,015 & 0,869 & 0,116 & 0,208 & $-0,024$ & 0,944 \\
Komunikasi aktif & 0,136 & 0,139 & 0,228 & $0,012^{*}$ & 0,006 & $0,019 *$ \\
Kognitif & 0,314 & $0,000^{*}$ & 0,285 & $0,002^{*}$ & 0,214 & 0,090 \\
Menolong diri sendiri & 0,152 & 0,098 & 0,134 & 0,145 & 0,090 \\
Tingkah laku sosial & 0,032 & 0,729 & 0,013 & 0,884 & $-0,035$ & 0,707 \\
\hline
\end{tabular}

*Signifikan berhubungan $(\mathrm{p}<0,05) ;{ }^{\mathrm{a}}=$ uji korelasi pearson $;{ }^{\mathrm{b}}=$ uji korelasi spearman

\section{PEMBAHASAN}

Usia 3-5 tahun yang disebut golden age merupakan periode kritis dan penting, tetapi dalam usia ini juga rawan terjadi gangguan gizi dan gangguan penyakit. Gizi pada anak balita sangat penting karena merupakan dasar kesehatan sepanjang hidup. Selain itu gizi pada balita juga berperan dalam kekuatan dan kemampuan intelektual. Jika dirangsang dengan tepat oleh lingkungan hidupnya, periode ini merupakan waktu yang tepat bagi seorang individu untuk memperoleh pengalaman, keterampilan maupun kemampuan secara optimal. ${ }^{15,16}$

Gizi merupakan salah satu faktor yang menentukan keberhasilan untuk mencapai tumbuh kembang optimal. Periode emas pertumbuhan disebut sebagai window of opportunity sehingga penting untuk menenuhi kebutuhan gizi anak. Bila pada masa periode emas pertumbuhan ini seorang anak dapat bertumbuh dan berkembang secara optimal, diharapkan pada masa dewasa akan tumbuh menjadi manusia yang berkualitas. Masalah gizi pada periode ini bersifat irreversible yang artinya tidak dapat diperbaiki lagi, sehingga jika terjadi kekurangan gizi maka akan memengaruhi perkembangan, morbiditas, dan mortalitas anak. ${ }^{15,17}$

Hasil penelitian ini menemukan bahwa status gizi indeks $\mathrm{BB} / \mathrm{U}$ signifikan berhubungan perkembangan motorik kasar $(\mathrm{p}=0,002 ; \mathrm{r}=0,284)$. Perkembangan motorik merupakan perkembangan kontrol pergerakan badan melalui koordinasi aktivitas saraf pusat, saraf tepi, dan otot yang dalam fungsinya tergantung pada maturasi saraf dan otot. Perkembangan motorik ini didukung dengan pertumbuhan dengan kematangan fisik. ${ }^{8}$ Penelitian ini juga menunjukkan bahwa status gizi BB/U berhubungan dengan perkembangan kognitif anak $(\mathrm{p}=0,000 ; \mathrm{r}=0,314)$. Penelitian yang dilakukan oleh Jimoh menyatakan bahwa anak underweight dibandingkan dengan anak yang memiliki status gizi $\mathrm{BB} / \mathrm{U}$ normal 3 kali lebih berisiko mengalami keterlambatan kemampuan komunikasi serta 5 kali lebih berisiko mengalami keterlambatan kemampuan interaksi sosial. ${ }^{18}$

Masalah status gizi indeks $\mathrm{TB} / \mathrm{U}$ atau stunting sering dihubungkan dengan kualitas hidup anak dan perkembangan anak terutama pada perkembangan motorik, kognitif dan bahasa. ${ }^{8,9,19}$ Penelitian ini menunjukkan hasil bahwa status gizi $\mathrm{TB} / \mathrm{U}$ berhubungan dengan perkembangan motorik kasar $(\mathrm{p}=0,000$; $\mathrm{r}=0,353)$, kognitif $(\mathrm{p}=0,002 ; \mathrm{r}=0,285)$ dan komunikasi aktif ( $\mathrm{p}=0,012 ; \mathrm{r}=0,228)$. Berdasarkan penelitian ini juga diketahui bahwa semakin baik indeks TB/U maka perkembangan motorik kasar, komunikasi aktif dan kognitif anak akan semakin baik. Hasil penelitian ini sejalan dengan penelitian Solihin yaitu terdapat kaitan 
antara status gizi $\mathrm{TB} / \mathrm{U}$ dengan perkembangan motori kasar, motorik halus, dan kognitif $(\mathrm{p}<0,05)$. Lebih lanjut Solihin menjelaskan bahwa setiap penambahan satu satuan $z$-zcore $\mathrm{TB} / \mathrm{U}$ balita, maka akan menambah tingkat perkembangan motorik balita sebesar $4,5 \%{ }^{7}$ Anak stunting yang tidak mengalami kelainan bawaan akan mengalami penurunan fungsi motorik dikaitkan dengan rendahnya kemampuan mekanik dari otot tricep surae yang mengakibatkan kematangan fungsi otot terlambat sehingga menyebabkan kemampuan motorik anak stunting terhambat. ${ }^{7,20}$

Hubungan status gizi TB/U dengan kemampuan kognitif balita terlihat pada ukuran kepala anak. Penelitian sebelumnya menunjukkan bahwa anak stunting mempunyai ukuran kepala yang lebih kecil sehingga berhubungan dengan volume otak dan daya berpikir. ${ }^{10}$ Anak stunting cenderung memiliki masalah pada pembelajaran, pemusatan perhatian, memori, dan kemampuan visuospatial. Selain itu, kemampuan aritmetik, mengeja, membaca kata dan membaca komprehensif pada anak stunting lebih rendah dibandingkan dengan anak yang tidak stunting. ${ }^{21}$ Penelitian yang dilakuka oleh Jimoh juga yang menyatakan bahwa anak stunting 2 kali lebih berisiko mengalami keterlambatan dalam mengembangkan kemampuan komunikasi. ${ }^{18}$ Penelitian yang dilakukan oleh Sudfeld menjelaskan bahwa dengan penambahan 0,10 satuan indeks z-score TB/U akan meningkatkan skor perkembangan komunikasi anak. ${ }^{8}$

Penelitian ini menunjukkan hubungan antara status gizi indeks $\mathrm{BB} / \mathrm{TB}$ dengan perkembangan motorik halus $(p=0,002 ; \quad r=0,276)$ dan kognitif $(p=0,019$; $\mathrm{r}=0,214)$. Hasil penelitian ini juga menunjukkan bahwa semakin baik indeks $\mathrm{BB} / \mathrm{TB}$ maka perkembangan motorik halus dan kognitif anak akan semakin baik. Hasil penelitian ini sejalan dengan penelitian lain yang juga menemukan bahwa status gizi $\mathrm{BB} / \mathrm{TB}$ berhubungan perkembangan motorik halus dan kognitif $(p<0,05){ }^{9,22}$ Status gizi $\mathrm{BB} / \mathrm{TB}$ sensitif terhadap perubahan berat badan dan memberikan indikasi masalah gizi yang sifatnya akut sebagai akibat dari peristiwa yang terjadi dalam waktu yang relatif singkat terjadi semisal infeksi penyakit tertentu atau kondisi kelaparan. Perubahan berat badan secara akut tersebut akan memengaruhi pertumbuhan dan perkembangan fisik. Perkembangan fisik saling berpengaruh dengan perkembangan motorik pada anak usia prasekolah. Proses belajar anak pra sekolah terkait gerak motorik memerlukan pengulangan dan bantuan orang lain. Setiap pengulangan tersebut memerlukan konsentrasi untuk melatih koneksitas dan koordinasi gerak dengan indera lainnya. ${ }^{23}$ Chowdhury menyatakan bahwa wasting merupakan salah satu faktor resiko keterlambatan perkembangan anak yang ditunjukkan dengan berkurangnya fungsi kognitif, gangguan fungsi kekebalan tubuh serta gangguan metabolisme tubuh yang dapat menyebabkan penyakit degenaratif dimasa mendatang. Wasting merupakan cerminan dari asupan gizi yang tidak adekuat dan komplikasi penyakit infeksi. Tidak hanya berdampak pada perkembangan anak, wasting juga menyebabkan peningkatan morbiditas dan mortalitas pada anak. ${ }^{24,25}$ Anak dengan status gizi normal cenderung memiliki perkembangan yang sesuai dengan capaian usianya sedangkan anak dengan masalah gizi cenderung mengalami perlambatan perkembangan.

\section{SIMPULAN}

Status gizi indeks BB/U berhubungan dan berkorelasi positif dengan perkembangan motorik kasar dan perkembangan kognitif. Status gizi indeks TB/U berhubungan dan berkorelasi positif dengan perkembangan motorik kasar, perkembangan komunikasi aktif, dan perkembangan kognitif. Status gizi indeks BB/TB berhubungan dan berkorelasi positif dengan perkembangan motorik halus dan perkembangan kognitif. Beberapa penelitian menunjukkan bahwa masalah perkembangan pada anak tidak hanya dipengaruhi oleh status gizi. Dukungan kesehatan, lingkungan, budaya masyarakat, pola hidup, serta stimulasi psikososial dari keluarga maupun lembaga pendidikan anak usia dini disebut menjadi aspek yang perlu diperhatikan guna memastikan anak dapat berkembangan sesuai dengan capaian yang semestinya. Keseluruhan aspek ini perlu diteliti lebih lanjut untuk menegakkan faktor pengaruh perkembangan anak.

\section{UCAPAN TERIMA KASIH}

Penulis mengucapkan terima kasih kepada The Nestle Foundation Switzerland yang telah mendukung penuh pembiayaan penelitian.

\section{DAFTAR PUSTAKA}

1. Bisai S, Mallick C. Prevalence of undernutrition among Kora-Mudi children aged 2-13 years in Paschim Medinipur District, West Bengal, India. World J Pediatr. 2011;7(1):31-6.

2. Suchdev PS, Jefferds MED, Ota E, da Silva Lopes K, De-Regil LM. Home fortification of foods with multiple micronutrient powders for health and nutrition in children under two years of age. Cochrane Database Syst Rev. 2020;2(2)

3. Junaidi. Pengaruh kecukupan zat gizi dan stimulasi pola asuh terhadap kesehatan intelegensi pada anak baduta. AcTion: Aceh Nutrition Journal. Mei 2017;2(1): 55-60.

4. Victora CG, de Onis M, Hallal PC, Blossner M, Shrimpton R. Worldwide timing of growth faltering: Revisiting implications for interventions. Pediatrics. 2010;125(3):473-80. 
5. Kementerian Kesehatan RI. Laporan Nasional Hasil Riset Kesehatan Dasar 2018. Jakarta: Kemenkes RI; 2018.

6. Dinkes Kabupaten Bogor. Profil Kesehatan Kabupaten Bogor Tahun 2016. Cibinong; 2017.

7. Solihin RDM, Anwar F, Sukandar D. Kaitan antara status gizi, perkembangan kognitif, dan perkembangan motorik pada anak usia prasekolah. Penelitian Gizi dan Makanan. The Journal of Nutrition and Food Research. 2013;36(1):62-72.

8. Sudfeld CR, McCoy DC, Fink G, Muhihi A, Bellinger DC, Masanja $\mathrm{H}$, et al. Malnutrition and Its Determinants Are Associated with Suboptimal Cognitive, Communication, and Motor Development in Tanzanian Children. J Nutr. 2015;145(12):2705-14.

9. Kang Y, Aguayo VM, Campbell RK, West Jr KP. Association between stunting and early childhood development among children aged 36-59 months in South Asia. Matern Child Nutr. Matern Child Nutr. 2018;14(S4):12684.

10. Grantham-McGregor S, Cheung YB, Cueto S, Glewwe P, Richter L, Barbara S. Developmental potential in the first 5 years for children in developing countries. Lancet. 2007;369(9555):6070.

11. Black MM, Walker SP, Fernald, LCH, Andersen CT, DiGirolamo AM, Lu C et al. Early childhood development coming of age: Science through the life course. Lancet. 2017;389(10064):77-90.

12. UNICEF. Programming Experiences in Early Child Development. New York : Early Child Development Unit Press; 2006.

13. Khomsan A. Teknik Pengukuran Pengetahuan Gizi. Bogor: Institusi Pertanian Bogor; 2000.

14. Warsito O, Khomsan A, Hernawati N, Anwar F. Relationship between nutritional status, psychosocial stimulation, and cognitive development in preschool children in Indonesia. Nutr Res Pract J. 2012;6(5):451-7.

15. Vinod, N; Swarnakanta, L; Smita, P; Pushpa D. Nutritional Status and Dietary Pattern of Underfive Children in Urban Slum Area. National Journal of Community Medicine. 2011;2(1):143-8.

16. Dariyo A. Psikologi Perkembangan Anak Tiga Tahun Pertama. Bandung: PT. Refika Adtama;
2007.

17. Chiruvu RT, Kanengoni B, Mungati M, Gombe NT, Bangure D, Tshimanga M, et al. Analysis of Trends in Nutritional Status and Morbidity of Under-Fives Among Internally Displaced Persons at Chingwizi, Mwenezi District, Zimbabwe 2014-2015. International Journal of Innovative Research \& Development. 2017;6(5):117-25.

18. Jimoh Ao, Anyiam JO, Yakubu AM. Relationship between child development and nutritional status of under-five Nigerian children. South African Journal of Clinical Nutrition. 2018; 31(3):50-4.

19. Muhoozi GKM, Atukunda P, Mwadime R, Iversen PO, Westerberg AC. Nutritional and developmental status among 6-to 8-month-old children in southwestern Uganda: a cross-sectional study. Food Nutr Res. 2016;60:30270.

20. Paiva MdG, Souza TOL, Canon F, Pérot C, Xavier LCC, Ferraz KM, et al. Stunting delays maturation of triceps surae mechanical properties and motor performance in prepubertal children. 112:40534061. Eur J Appl Physiol. 2012;112:4053-61.

21. Laus MF, Duarte Manhas Ferreira Vales L, Braga Costa TM, Sousa Almeida S. Early postnatal protein-calorie malnutrition and cognition: a review of human and animal studies. Int J Env Res Public Health. 2011;8(2):590-612.

22. Subasinghe SMLP, Wijesinghe DGNG. The effect of nutritional status on cognitive and motor development of preschool children. Tropical Agricultural Research. 2006;18:1-9.

23. Nyaradi A, Li J, Hickling S, Foster J, Oddy WH. The role of nutrition in children's neurocognitive development, from pregnancy through childhood. Front Hum Neurosc. 2013:26(7):97.

24. Chowdhury MH, Shill LC, Purba NH, Rabbi FA, Chowdhury MJ. Adverse Effect of Micronutrient Deficiencies on Children's Development: The Wasting Syndrome. Food Nutr Curr Res. 2019;2(1):136-48.

25. Ahmed T, Mahfuz M, Ireen S, Ahmed AS, Rahman S, Islam MM, Alam N, Hossain MI, Rahman SM, Ali MM, Choudhury FP. Nutrition of children and women in Bangladesh: trends and directions for the future. Journal Health Popul Nutr. 2012;30(1):1. 